\title{
Does presence of anterior greater tuberosity cysts change the function in patients with chronic rotator cuff tear?
}

\author{
Anterior büyük tüberkül kistlerinin varlığı kronik rotator manşet yırtığı \\ bulunan hastalarda fonksiyonu değiştirir mi?
}

\author{
Selda Başar, PT. PhD., ${ }^{1}$ Ulunay Kanatlı, M.D., ${ }^{2}$ Seyit Çıtaker, PT., ${ }^{1}$ Selçuk Bölükbaşı, M.D. ${ }^{2}$ \\ 1Department of Physiotherapy and Rehabilitation, Gazi University Faculty of Health Sciences, Ankara, Turkey \\ ${ }^{2}$ Department of Orthopedics and Traumatology, Medical Faculty of Gazi University, Ankara, Turkey
}

\begin{abstract}
Objectives: This study aims to compare rotator cuff muscle atrophy with fatty degeneration, tear size, range of motion, shoulder muscle strength, pain and upper extremity function in patients with chronic rotator cuff tear, and with or without anterior greater tuberosity cyst.
\end{abstract}

Patients and methods: A total of 101 patients (32 males, 69 females; mean age $51 \pm 12.9$ years; range 17 to 76 years) were evaluated in this study. Fifty-eight patients were excluded due to traumatic or acute rotator cuff tears and neck pain. Forty-three patients of chronic rotator cuff tear were divided into two groups as patients with $(n=15)$ and without $(n=28)$ an anterior greater tuberosity cyst. Patients were evaluated for range of motion, shoulder muscle strength, pain and upper extremity function, and radiologically. Statistical differences were investigated between two groups.

Results: The number of patients with tears larger than $1 \mathrm{~cm}$ and the number of patients who had muscle atrophy were higher in the group of patients with a cyst. Also, upper extremity function was reduced in the group of patients with a cyst (Western Ontario Rotator Cuff Index, $p=0.03$, Nine-Hole Peg Test, $\mathrm{p}=0.02$ ).

Conclusion: Our findings demonstrated that decreased function, larger cuff tears and muscle atrophy can be observed patients with anterior greater tuberosity cysts. Anterior greater tuberosity cysts can be detected by plain X-rays. The presence of these cysts should warn the physician regarding the possibility of decreased shoulder function, muscle atrophy and larger cuff tear before ordering a magnetic resonance imaging. Keywords: Cyst; functional outcome; muscle atrophy; rotator cuff tears; shoulder.
Amaç: Bu çalışmada anterior büyük tüberkül kisti bulunan ve bulunmayan, kronik rotator manşet yırtığı olan hastalarda yağlı dejenerasyonlu rotator manşet kas atrofisi, yırtık boyutu, eklem hareket açıklığı, omuz kas kuvveti, ağrı ve üst ekstremite fonksiyonu karşılaştırıldı.

Hastalar ve yöntemler: Bu çalışmada toplam 101 hasta (32 erkek, 69 kadın; ort. yaş 51 \pm 12.9 yıl; dağılım 17-76 yıl) değerlendirildi. Elli sekiz hasta travmatik veya akut rotator manşet yırtığı ve boyun ağrısı nedeniyle çalışma dişında bırakıldı. Kronik rotator manşet yırtığ 1 olan 43 hasta, anterior büyük tüberkül kisti bulunan $(n=15)$ ve bulunmayan $(n=28)$ hastalar olmak üzere iki gruba ayrıldı. Hastalar eklem hareket açıklığı, omuz kas kuvveti, ağrı, üst ekstremite fonksiyonu açısından ve radyolojik açıdan değerlendirildi. İki grup arasında istatistiksel farklılıklar araştırıldı.

Bulgular: Kisti olan hastaların bulunduğu grupta 1 cm'den büyük yırtığ 1 olan hasta sayısı ile kas atrofisi bulunan hasta sayısı daha fazlaydı. Kisti olan hasta grubunda üst ekstremite fonksiyonu da azalmıştı (Western Ontario Rotator Manşet İndeksi, $\mathrm{p}=0.03$, Dokuz Delikli Peg testi, $\mathrm{p}=0.02$ ).

Sonuç: Bulgularımız anterior büyük tüberkül kisti bulunan hastalarda fonksiyonda azalma, daha büyük manşet yırtığı ve kas atrofisi görülebileceğini gösterdi. Anterior büyük tüberkül kistleri direkt grafide tespit edilebilir. Bu kistlerin varlığ manyetik rezonans görüntüleme istemeden önce azalmış omuz fonksiyonu, kas atrofisi ve daha büyük manşet yırtı̆̆ı olabileceği hakkında hekimi uyarmalıdır.

Anahtar sözcükler: Kist; fonksiyonel sonuç; kas atrofisi; rotator manşet yırtığı; omuz.

- Received: October 01, 2013 Accepted: April 28, 2014

- Correspondence: Selda Başar, M.D. Muammer Yașar Bostancı Cad., Emniyet Mah., No: 16, 06500 Beşevler, Ankara, Turkey. Tel: +90 312 - 2162633 Fax: +90 312 - 2162636 e-mail: seldabsr@yahoo.com 
Rotator cuff tears (RCT) are one of the most common problems. ${ }^{[1]}$ These tears may cause shoulder pain and functional loss of upper extremity. ${ }^{[1,2]}$ Reduced function may be caused by pain, muscle weakness, limited range of motion, tear size, number of tendons with tear, and quality of muscle (atrophy and fatty degeneration) in symptomatic RCTs. ${ }^{[2-5]}$

Intact rotator cuff tendon protects the tuberosity against cyst formation by constituting a structural barrier against synovial fluid. ${ }^{[6,7]}$ In case of a RCT, this natural barrier is disrupted, leaving the rotator cuff footprint vulnerable to synovial fluid exposure. ${ }^{[6,7]}$ Moreover, the tendon may cause breaching points on the cortical bone as it continues to tear and exerts extra pulling force on greater tuberosity. This results in leakage of synovial fluid into the exposed areas, causing formation of synovial tissue which, in turn, leads to cyst formation. ${ }^{[8]}$ The humeral head cyst can be divided into anterior and posterior groups in terms of their location on tuberosities. Posterior cysts that are located on tuberculum majus are also divided into anterior and posterior parts. Anterior group of posterior cysts are known to be strongly associated with RCTs. ${ }^{[9-11]}$

To our knowledge, there is no study comparing muscle atrophy of the rotator cuff, tear size, shoulder muscle strength, range of motion (ROM), pain, and upper extremity function between RCT patients with or without anterior greater tuberosity cyst (AGTC).

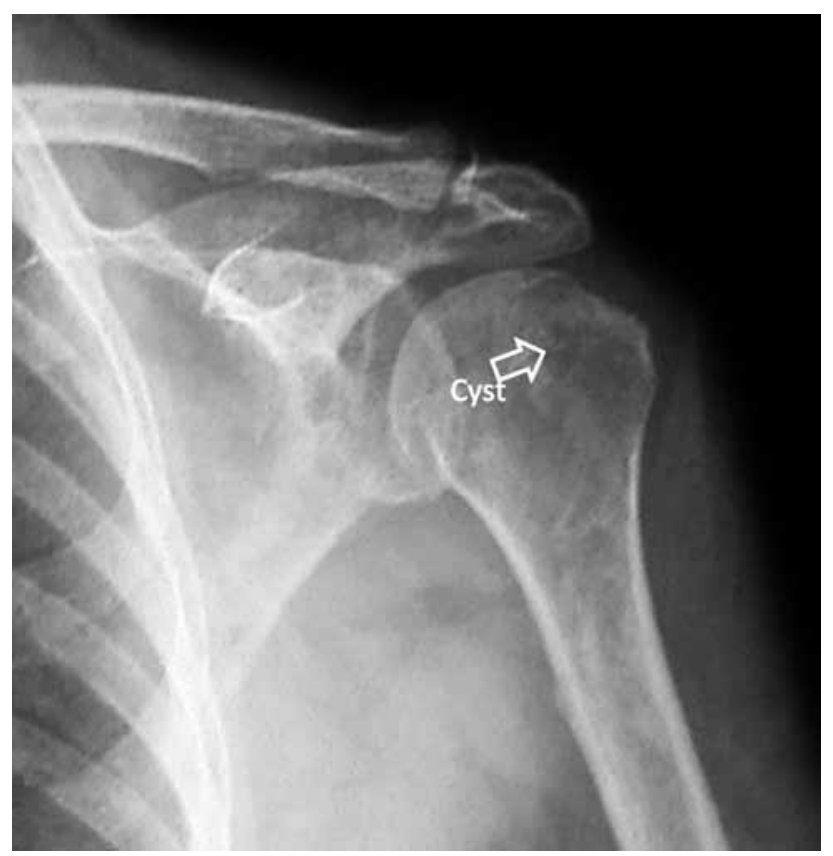

Figure 1. Plain X-rays facilitates localization of subchondral cycsts.
These factors would change depending on rotator cuff pathology that causes AGTC. Therefore, in this study, we aimed to compare rotator cuff muscle atrophy with fatty degeneration, tear size, range of motion, shoulder muscle strength, pain and upper extremity function in patients with chronic RCT, and with or without AGTC. At the same time, the answer of the following question will be sought in this study: Does the presence of AGTC change the functional outcomes of patients with chronic RCT?

\section{PATIENTS AND METHODS}

This study was approved and performed in accordance with the guidelines of the institutional review board at Gazi University, and all patients completed informed consent to participate in the study. A total of 101 patients ( 32 males, 69 females; mean age $51 \pm 12.9$ years; range 17 to 76 years) were evaluated between January 2011 and December 2012. Fifty-eight patients were excluded, including 44 due to traumatic RCT, eight due to neck pain, and six due to acute RCT.

Patients were excluded if they were diagnosed with any neurologic condition, and had a history of prior shoulder surgery, rheumatoid arthritis, acute RCTs (less than three months), bilateral RCTs, glenohumeral joint osteoarthritis, dislocation, fracture, and adhesive capsulitis. Participants were divided into two groups as patients with $(n=15)$ and without $(n=28)$ an AGTC.

Subchondral cysts can be detected easily on plain X-rays (Figure 1). The tear sizes were classified according to the system described by Cofield et al. ${ }^{[11]}$

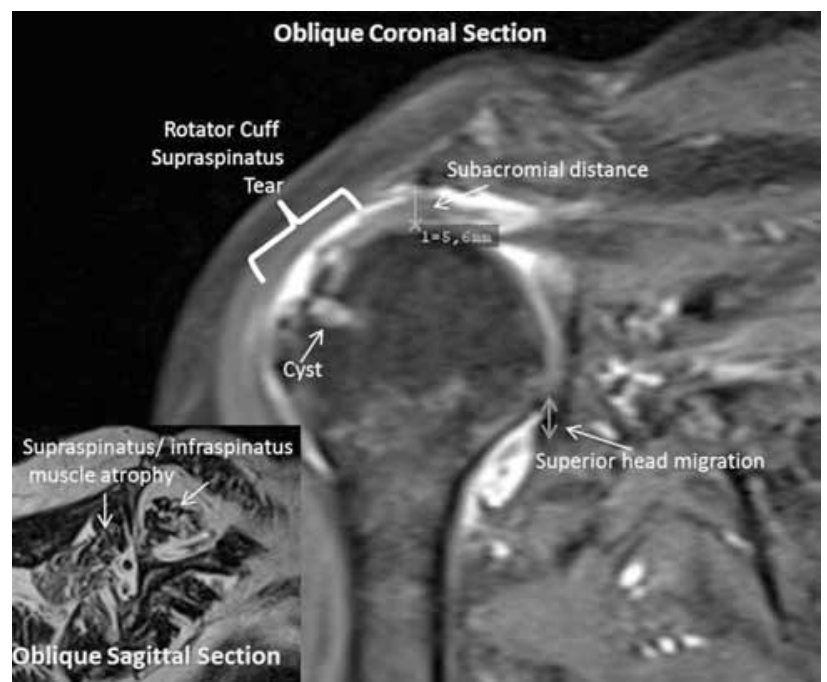

Figure 2. Oblique coronal magnetic resonance imaging shows the subchondral cyst, superior migration of humeral head, rotator cuff tear and narrowing of subacromial distance. Supraspinatus and infraspinatus muscle atrophy can be classified on oblique sagittal magnetic resonance imaging. 
Involvement and retraction of the rotator cuff tendons were assessed with standard, non-contrast coronal, axial and sagittal magnetic resonance imaging (MRI) sequences, as described by Thomazeau et al. ${ }^{[12]}$ The presence of a humeral head migration was evaluated on true anteroposterior shoulder radiographs (positive if acromiohumeral distance $<7 \mathrm{~mm}$ ). ${ }^{[13]}$ The fatty degeneration of the rotator cuff musculature was graded on the system described by Goutallier et al. ${ }^{[14]}$ The presence of cystic changes in rotator cuff footprint (major and minor tuberosities) was also recorded based on MRI findings (Figure 2).

Active internal and external rotation were measured in the supine position, while active shoulder elevation was measured in the standing position with a universal goniometer. The muscle strength of shoulder internal and external rotators (with an arm in neutral adduction and elbow in $90^{\circ}$ flexion) were measured with a digital hand dynamometer (Baseline $^{\circledR}$ according to the criteria of the American Academy of Orthopaedic Surgeons). Supraspinatus muscle strength was evaluated in full can position. ${ }^{[15]}$ Patients were asked to mark their current shoulder pain on a visual analog scale (range from 0 to 10). Upper extremity function was determined through Nine-Hole Peg Test (NHPT) ${ }^{[16]}$ and Western Ontario Rotator Cuff Index (WORC). ${ }^{[1]}$

\section{Statistical analysis}

Overall summary of statistics were assessed for normality, and the means and standard deviations were calculated as continuous variables. Frequencies and percentages were collected for the categorical variables. Migration and cyst were categorized as present or absent, retraction was

TABLE I

Patients- and tear-specific demographics

\begin{tabular}{|c|c|c|c|c|}
\hline & \multicolumn{2}{|c|}{ Cyst absent } & \multicolumn{2}{|c|}{ Cyst present } \\
\hline & $\mathrm{n}$ & $\%$ & $\mathrm{n}$ & $\%$ \\
\hline \multicolumn{5}{|l|}{ Involved shoulder } \\
\hline Right & 13 & 46.4 & 7 & 46.7 \\
\hline Left & 15 & 53.6 & 8 & 53.3 \\
\hline \multicolumn{5}{|l|}{ Gender } \\
\hline Male & 10 & 35.7 & 2 & 13.3 \\
\hline Female & 18 & 64.3 & 13 & 86.7 \\
\hline \multicolumn{5}{|l|}{ Degree of tear retraction } \\
\hline Minimal & 20 & 71.4 & 5 & 33.3 \\
\hline Midhumeral & 7 & 25.0 & 7 & 46.7 \\
\hline Glenohumeral & 1 & 3.6 & 2 & 13.3 \\
\hline Medial to glenoid & - & - & 1 & 6.7 \\
\hline \multicolumn{5}{|l|}{ Tear tendon } \\
\hline Only supraspinatus & 24 & 85.7 & 8 & 53.3 \\
\hline Supraspinatus + infraspinatus & 2 & 7.1 & 2 & 13.3 \\
\hline Supraspinatus + subscapularis & 2 & 7.1 & 4 & 26.7 \\
\hline Supraspinatus + infraspinatus + subscapularis & - & - & 1 & 6.7 \\
\hline \multicolumn{5}{|l|}{ Tear size } \\
\hline$<1 \mathrm{~cm}$ & 18 & 64.3 & 7 & 46.7 \\
\hline $1-3 \mathrm{~cm}$ & 7 & 25.0 & 4 & 26.7 \\
\hline $3-5 \mathrm{~cm}$ & 3 & 10.7 & 3 & 20.0 \\
\hline$>5$ & - & - & 1 & 6.6 \\
\hline \multicolumn{5}{|l|}{ Muscle atrophy } \\
\hline Normal muscle & 11 & 39.3 & 3 & 20.0 \\
\hline Muscle>fat & 15 & 53.6 & 9 & 60.0 \\
\hline Muscle $=$ fat & 2 & 7.1 & 3 & 20.0 \\
\hline \multicolumn{5}{|l|}{ Humeral head migration } \\
\hline No (Acromiohumeral space $>7 \mathrm{~mm}$ ) & 27 & 96.4 & 8 & 53.3 \\
\hline Yes (Acromiohumeral space $<7 \mathrm{~mm}$ ) & 1 & 3.6 & 7 & 46.7 \\
\hline
\end{tabular}


categorized as minimal or more than minimal, while tear size was classified as small or large, tear extension was classified as involving one or more tendons, and atrophy was categorized as normal or severe. The proportions of patients were presented according to this classification. The chi-square test or Fisher's exact test, where appropriate, was used to compare these proportions in the groups. Group differences among discrete variables were evaluated using Student T-test or Mann-Whitney U test. All tests were evaluated using two-sided hypothesis testing with statistical significance set to $p=0.05$. Calculations were performed using PASW version 18 (formerly SPSS Software, SPSS Inc., Chicago, IL, USA).

\section{RESULTS}

Nine patients (36\%) in the group of patients without a cyst did not have an additional shoulder pathology, while nine patients (32\%) had type 2 superior labrum anterior-posterior lesion (SLAP 2), six patients (21\%) had biceps pathology, and three patients had (12\%) acromioclavicular joint degeneration. Five patients (33\%) in the group of patients with a cyst did not have additional shoulder pathology, whereas two patients (13\%) had SLAP 2, four patients $(27 \%)$ had biceps pathology, and two patients (13\%) had acromioclavicular joint degeneration. Patient- and tear-specific demographics are shown in Table 1.
Patients who had a retraction, which was more than minimal, patients who had a tear tendon number in addition to supraspinatus muscle, patients who had a tear larger than $1 \mathrm{~cm}$, patients who had muscle $>$ fat and muscle $=$ fat muscle, and patients who had a migration with a cyst had a higher score in the group of patients with a cyst (Table 2).

Active elevation in ROM significantly decreased in the group of patients with a cyst $(\mathrm{p}<0.05)$. Although internal, external rotators and supraspinatus muscle strength had a tendency to decrease in the group of patients with a cyst, no significant difference was detected between the two groups ( $>>0.05)$. Variables for rest, $>90^{\circ}$ abduction, package carrying, and pain at night were similar ( $p>0.05)$. The Nine-Hole Peg Test and WORC scores were lower in the group of patients with a cyst $(\mathrm{p}<0.05)$ (Table 3$)$.

\section{DISCUSSION}

The current study showed that the total number of patients having supraspinatus with an additional tear tendon, and also a rotator cuff muscle atrophy with fatty degeneration were higher in the group of patients with a cyst. Active elevation of the shoulder and upper extremity function were affected negatively in patients with RCT and concomitant humeral head cysts.

In terms of clinical findings, it can be said that the amount of retraction, with additional tendons

\section{TABLE II}

Comparison of proportion of patients between groups

\begin{tabular}{|c|c|c|c|c|c|}
\hline & \multicolumn{4}{|c|}{ Cyst } & \multirow[b]{3}{*}{$p$} \\
\hline & \multicolumn{2}{|c|}{ Absent } & \multicolumn{2}{|c|}{ Present } & \\
\hline & $\mathrm{n}$ & $\%$ & $\mathrm{n}$ & $\%$ & \\
\hline \multicolumn{6}{|l|}{ Degree of tear retraction } \\
\hline Minimal & 20 & 71.4 & 5 & 33.3 & \\
\hline More than minimal & 8 & 28.6 & 10 & 66.7 & 0.01 \\
\hline \multicolumn{6}{|l|}{ Tear tendon } \\
\hline Only supraspinatus & 24 & 85.7 & 8 & 53.3 & \\
\hline 2-4 tendon & 4 & 14.2 & 7 & 47.7 & 0.01 \\
\hline \multicolumn{6}{|l|}{ Tear size } \\
\hline Small $<1 \mathrm{~cm}$ & 18 & 64.3 & 7 & 46.7 & \\
\hline Large $>1 \mathrm{~cm}$ & 7 & 35.7 & 8 & 53.3 & 0.02 \\
\hline \multicolumn{6}{|l|}{ Muscle atrophy } \\
\hline Absent & 11 & 39.3 & 3 & 20.0 & \\
\hline Severe & 17 & 60.7 & 12 & 80.0 & 0.03 \\
\hline \multicolumn{6}{|l|}{ Humeral head migration } \\
\hline Absent (Acromiohumeral space $>7$ mm) & 27 & 96.4 & 8 & 53.3 & \\
\hline Present (Acromiohumeral space $<7 \mathrm{~mm}$ ) & 1 & 3.6 & 7 & 46.7 & 0.00 \\
\hline
\end{tabular}


TABLE III

Comparison of range of motion, muscle strength, pain, symptom duration and function between the groups

\begin{tabular}{|c|c|c|c|c|c|c|c|}
\hline \multirow[t]{2}{*}{ Parameters } & \multicolumn{3}{|c|}{ Cyst (-) (n=28) } & \multicolumn{3}{|c|}{ Cyst $(+)(n=15)$} & \multirow[b]{2}{*}{$p$} \\
\hline & Mean $\pm S D$ & Median & IQR & Mean $\pm S D$ & Median & IQR & \\
\hline Age (year) & $54.0 \pm 9.7$ & 53.0 & $46.0-63.0$ & $59.3 \pm 12.1$ & 62.5 & $51.0-67.0$ & 0.040 \\
\hline Body mass index $\left(\mathrm{kg} / \mathrm{cm}^{2}\right)$ & $28.6 \pm 5.1$ & 28.2 & 23.9-32.0 & $31.8 \pm 4.0$ & 31.2 & $30.8-34.5$ & 0.075 \\
\hline Symptom duration (month) & $16.4 \pm 19.6$ & 10.5 & $4.0-24.0$ & $21.2 \pm 22.7$ & 12.0 & $8.0-30.0$ & 0.309 \\
\hline \multicolumn{8}{|l|}{ Range of motion } \\
\hline Internal rotation & $82.6 \pm 17.2$ & 90.0 & $90.0-90.0$ & $73.0 \pm 22.6$ & 90.0 & $47.0-90.0$ & 0.118 \\
\hline External rotation & $76.1 \pm 20.2$ & 90.0 & $62.5-90.0$ & $64.6 \pm 32.6$ & 90.0 & $30.0-90.0$ & 0.401 \\
\hline Elevation & $154.9 \pm 22.9$ & 160.0 & $151.0-165.0$ & $141.2 \pm 22.5$ & 149.0 & $135.0-152.0$ & 0.031 \\
\hline \multicolumn{8}{|l|}{ Muscle strength } \\
\hline Strength of internal rotators & $26.4 \pm 11.9$ & 24.5 & $20.0-27.0$ & $22.3 \pm 7.0$ & 23.0 & $18.0-26.0$ & 0.309 \\
\hline Strength of external rotators & $22.5 \pm 6.9$ & 21.5 & $16.0-30.0$ & $20.0 \pm 7.2$ & 20.0 & $13.0-25.0$ & 0.356 \\
\hline Supraspinatus & $26.5 \pm 12.4$ & 25.0 & $20.0-33.0$ & $24.0 \pm 12.3$ & 22.0 & $15.0-33.0$ & 0.481 \\
\hline \multicolumn{8}{|l|}{ Pain } \\
\hline At rest & $4.8 \pm 3.2$ & 5.0 & $2.0-6.7$ & $2.8 \pm 3.6$ & 0.0 & $0.0-5.0$ & 0.057 \\
\hline$>90^{\circ}$ abduction & $6.4 \pm 3.0$ & 7.0 & $4.5-10.0$ & $5.7 \pm 3.5$ & 7.0 & $2.5-8.0$ & 0.542 \\
\hline Package carrying & $7.3 \pm 3.4$ & 9.4 & $5.0-10.0$ & $6.3 \pm 4.0$ & 7.5 & $2.5-10.0$ & 0.550 \\
\hline At night & $7.8 \pm 3.3$ & 9.0 & $6.5-10.0$ & $7.7 \pm 3.3$ & 10.0 & $6.1-10.0$ & 0.900 \\
\hline \multicolumn{8}{|l|}{ Function } \\
\hline Nine Hole Peg Test & $20.0 \pm 2.6$ & 19.2 & $18.1-21.6$ & $22.1 \pm 3.2$ & 22.4 & $19.3-24.3$ & 0.032 \\
\hline Western Ontario Rotator & & & & & & & \\
\hline Cuff Index & $56.8 \pm 29.5$ & 52.0 & $27.5-87.0$ & $39.1 \pm 27.7$ & 27.3 & $20.1-43.1$ & 0.024 \\
\hline
\end{tabular}

supraspinatus tear, tear size (larger than $1 \mathrm{~cm}$ ), fatty infiltration, and muscle atrophy increased in patients with cysts compared to those without cysts. In other words, radiologic findings are worse in patients with AGTC. The cysts under the foot print of rotator cuff muscles formed after radiologic findings improved. Since, to the best of our knowledge, there is no study investigating similar parameters in patients with RCT and concomitant humeral head cysts, we were unable to compare the results of the current study with the literature.

A significant finding in this study was that active elevation in ROM decreased in the group of patients with a cyst. To the best of our knowledge, no study has been reported in the literature comparing the shoulder ROM between patients with RCT, and with or without AGTC. Therefore, the current study can be the first to present this data. According to Beeler et al. ${ }^{[18]}$ and Harris et al., ${ }^{[19]}$ decreased active ROM in patients deteriorates upper extremity functions. In accordance with the results of this study, the changes related to cyst and concomitant RCT reduced internal and external rotation ROM. However, the difference was not statistically significant. On the other hand, active abduction degree is an indicator of function in patients who have RCT. The movement restriction in more than one way of shoulder joint in patients with AGTC indicates that they can face challenges in setting their arm in the needed position while performing daily activities. Although it has been shown that abduction movement is a predictor of function in patients with RCT, the condition in patients with AGTC can be different. Therefore, it is thought that active elevation can be a predictor of function in patients with RCT and AGTC. However, this subject was not investigated in this study.

In this study, although internal and external rotator muscle of the shoulder was weaker in the group of patients with a cyst compared to the other group, the difference was not significant. It can be stated that the reason why muscle strength did not change significantly was that the majority of patients in two groups had small tear size, and that torn muscle in most of the patients included only the supraspinatus tendon. Although it has been shown that the elevation and abduction strength are among factors that determine WORC scores in patients with $\mathrm{RCT}_{,}{ }^{[19]}$ it has also been reported that internal and external rotation strength do not have a direct relationship with the upper extremity functional performance or WORC scores in healthy shoulders. ${ }^{[20]}$ Harris et al. ${ }^{[19]}$ pointed out that strength of forward elevation and abduction 
were related to shoulder pain. To our knowledge, there is no study comparing shoulder pain in RCT patients with AGTC. In the current study, shoulder pain level was similar in both groups. Although radiologic findings improved, there can be many reasons why level of pain did not change. The relation between tear size and pain level has not been shown yet. On the other hand, changing thresholds can be a factor as well. From this point of view, pain level is not considered as a distinctive clinical finding in patients with or without AGTC.

Nine-Hole Peg Test is a standardized, validated, and objective method used to determine hand and upper extremity function. ${ }^{[16,21-23]}$ This test is based on performance while WORC is a scale where patients grade their own functional state. Therefore, both of the assessments were carried out. The most significant finding of this study was that upper extremity function decreased in accordance with both WORC score and NHPT in the group of patients with a cyst. Gladstone et al. ${ }^{[3]}$ maintained that chronic tendon tears disrupt the shoulder function. In a previous study, shoulder function was associated to active ROM in healthy patients and patients having RCT. ${ }^{[19]} \mathrm{It}$ was thought that the reason why function decreased in the group of patients with cyst was the reduced elevation in ROM. Further studies on upper extremity function and related parameters should be conducted on patients diagnosed with RCT, and with or without AGTC. In addition, the presence of AGTC should be considered in terms of clinical and radiologic status, function, and treatment plan in patients with RCT.

Due to the limited number of subjects, we were unable to perform further analyses to show whether elevation in ROM is a predictor of function. Also, the results of this study cannot be generalized for all RCT patients since chronic RCT patients were included in the study.

\section{Conclusion}

In this study, we showed that RCT atrophy and tear size increased while active ROM and upper extremity function decreased in the patients diagnosed with RCT, and who have an AGTC. However, muscle strength of rotator cuff and shoulder pain level did not change. According to the results of this study, poor function was related to the size and atrophy of RCT which increases the formation of cysts under the foot print of rotator cuff muscles. We conclude that RCT patients with cysts can have lower functional results than RCT patients without cysts. Physicians can use plain X-rays to detect cysts localized at greater tuberosity, and inform patients with cysts that the results of their treatment might not be satisfactory for both the patient and physician.

Response to the question: Rotator cuff tear patients with cysts had lower functional results than RCT patients without cysts.

\section{Acknowledgments}

We acknowledge Assoc. Prof. Bülent Çelik for his contribution to the statistical analyzing of the data

\section{Declaration of conflicting interests}

The authors declared no conflicts of interest with respect to the authorship and/or publication of this article.

\section{Funding}

The authors received no financial support for the research and/or authorship of this article.

\section{REFERENCES}

1. Büker N, Kitiş A, Akkaya S, Akkaya N. Comparison of the results of supervised physiotherapy program and home-based exercise program in patients treated with arthroscopic-assisted mini-open rotator cuff repair. [Article in Turkish] Eklem Hastalik Cerrahisi 2011;22:134-9.

2. Ulaşlı AM, Erkeç S, Uyar S, Nacır B, Yılmaz Ö, Erdem HR. The effect of acromioclavicular joint degeneration on orthopedic shoulder tests. Eklem Hastalik Cerrahisi 2013;24:77-81.

3. Gladstone JN, Bishop JY, Lo IK, Flatow EL. Fatty infiltration and atrophy of the rotator cuff do not improve after rotator cuff repair and correlate with poor functional outcome. Am J Sports Med 2007;35:719-28.

4. Yamaguchi $\mathrm{K}$, Ditsios $\mathrm{K}$, Middleton WD, Hildebolt CF, Galatz LM, Teefey SA. The demographic and morphological features of rotator cuff disease. A comparison of asymptomatic and symptomatic shoulders. J Bone Joint Surg [Am] 2006;88:1699-704.

5. Yamaguchi K, Sher JS, Andersen WK, Garretson R, Uribe JW, Hechtman K, et al. Glenohumeral motion in patients with rotator cuff tears: a comparison of asymptomatic and sympomatic shoulders. J Shoulder Elbow Surg 2000;9:6-11.

6. Fritz LB, Ouellette HA, O'Hanley TA, Kassarjian A, Palmer WE. Cystic changes at supraspinatus and infraspinatus tendon insertion sites: association with age and rotator cuff disorders in 238 patients. Radiology 2007;244:239-48.

7. Resnick D, Niwayama G, Coutts RD. Subchondral cysts (geodes) in arthritic disorders: pathologic and radiographic appearance of the hip joint. AJR Am J Roentgenol 1977;128:799-806.

8. Ruotolo C, Fow JE, Nottage WM. The supraspinatus footprint: an anatomic study of the supraspinatus insertion. Arthroscopy 2004;20:246-9.

9. Suluova F, Kanatli U, Ozturk BY, Esen E, Bolukbasi S. Humeral head cysts: association with rotator cuff tears and age. Eur J Orthop Surg Traumatol 2014;24:733-9.

10. Sano A, Itoi E, Konno N, Kido T, Urayama M, Sato K. Cystic changes of the humeral head on MR imaging. Relation to age and cuff-tears. Acta Orthop Scand 1998 ;69:397-400. 
11. Cofield RH, Parvizi J, Hoffmeyer PJ, Lanzer WL, Ilstrup $\mathrm{DM}$, Rowland CM. Surgical repair of chronic rotator cuff tears. A prospective long-term study. J Bone Joint Surg [Am] 2001;83:71-7.

12. Thomazeau H, Boukobza E, Morcet N, Chaperon J, Langlais F. Prediction of rotator cuff repair results by magnetic resonance imaging. Clin Orthop Relat Res 1997;344:275-83.

13. Ellman H, Hanker G, Bayer M. Repair of the rotator cuff. End-result study of factors influencing reconstruction. J Bone Joint Surg [Am] 1986;68:1136-44.

14. Goutallier D, Postel JM, Bernageau J, Lavau L, Voisin MC. Fatty muscle degeneration in cuff ruptures. Pre- and postoperative evaluation by CT scan. Clin Orthop Relat Res 1994;304:78-83.

15. Itoi E, Kido T, Sano A, Urayama M, Sato K. Which is more useful, the "full can test" or the "empty can test," in detecting the torn supraspinatus tendon? Am J Sports Med 1999;27:65-8.

16. Earhart GM, Cavanaugh JT, Ellis T, Ford MP, Foreman $\mathrm{KB}$, Dibble L. The 9-hole PEG test of upper extremity function: average values, test-retest reliability, and factors contributing to performance in people with Parkinson disease. J Neurol Phys Ther 2011;35:157-63.

17. El O, Bircan C, Gulbahar S, Demiral Y, Sahin E, Baydar M, et al. The reliability and validity of the Turkish version of the Western Ontario Rotator Cuff Index. Rheumatol Int 2006;26:1101-8.
18. Beeler S, Ek ET, Gerber C. A comparative analysis of fatty infiltration and muscle atrophy in patients with chronic rotator cuff tears and suprascapular neuropathy. J Shoulder Elbow Surg 2013;22:1537-46.

19. Harris JD, Pedroza A, Jones GL; MOON (Multicenter Orthopedic Outcomes Network) Shoulder Group. Predictors of pain and function in patients with symptomatic, atraumatic full-thickness rotator cuff tears: a time-zero analysis of a prospective patient cohort enrolled in a structured physical therapy program. Am J Sports Med 2012;40:359-66.

20. Roy JS, Macdermid JC, Boyd KU, Faber KJ, Drosdowech D, Athwal GS. Rotational strength, range of motion, and function in people with unaffected shoulders from various stages of life. Sports Med Arthrosc Rehabil Ther Technol 2009;1:4.

21. Oxford Grice K, Vogel KA, Le V, Mitchell A, Muniz S, Vollmer MA. Adult norms for a commercially available Nine Hole Peg Test for finger dexterity. Am J Occup Ther 2003;57:570-3.

22. Mathiowetz V, Volland G, Kashman N, Weber K. Adult norms for the Box and Block Test of manual dexterity. Am J Occup Ther 1985;39:386-91.

23. Kellor M, Frost J, Silberberg N, Iversen I, Cummings R. Hand strength and dexterity. Am J Occup Ther 1971;25:77-83. 